\title{
Resenhas críticas: sobre livros, leituras e leitores críticos
}

"Antes de mais nada, pinto pintura.

E antes de mais nada, te escrevo dura escritura"

(Clarice Lispector 1, p. 13).

No mundo editorial qual seria o lugar de uma resenha crítica? A resposta a essa questão está relacionada a outras duas que devem guiar qualquer exercício de elaboração de um texto acadêmico: o que queremos e sobre o que desejamos escrever, pesquisar, comunicar? Em que lugar nos situamos quando pretendemos publicizar resultados de pesquisas ou produzir conhecimento na forma de artigos originais, artigos de opinião, ensaios teóricos e aqui, em nossas lentes, resenhas críticas de livros?

Por meio de seus editoriais, CSP tem nos provocado a refletir e debater sobre os processos que envolvem a produção do conhecimento e a divulgação científica no campo da Saúde Pública/Saúde Coletiva 2,3,4. Esse Editorial cumpre ao menos duas funções: (1) reconhecer que pouco esclarecemos aos autores sobre o que consideramos relevante em um artigo no estilo de resenha crítica; (2) valorizar a função autoral e de divulgação acadêmica atualizada que uma resenha crítica pode oferecer. Nesse sentido, valorizar os livros, desenvolver a interpretação e a crítica na leitura, pode se tornar um belo exercício de cultivo e de estímulo a novos autores: que sejam criativos, analíticos, leiam, interpretem e não produzam e reproduzam a cultura do plágio e do pastiche. A resenha crítica como estilo de texto acadêmico produz um círculo virtuoso de ler/oferecer/retribuir. Ela reconhece tanto o autor do livro e a obra, quanto faz com que esse leitor, ao se tornar autor e crítico pela resenha construída, alcance outros possíveis leitores, conquistando, inquietando, provocando o desejo de ler e escrever.

Em uma rápida busca por periódicos da área de Saúde Coletiva/Saúde Pública e de Ciências Humanas e Sociais, reconhecemos uma lacuna sobre o que uma resenha crítica no formato acadêmico deve contemplar. Talvez porque ainda valorizemos pouco esse estilo acadêmico, e porque precisemos estimular e valorizar a iniciação de novos leitores que exercitem a interpretação, análise e discussão crítica.
${ }_{1}^{1}$ Instituto Nacional de Saúde da Mulher, da Criança e do Adolescente Fernandes Figueira, Fundação Oswaldo Cruz, Rio de Janeiro, Brasil. 
Alves Filho \& Alves 5 sintetizam o autor como aquele que assume e é reconhecido como a autoridade que detém o poder de interpretação em uma obra. Em uma retomada histórica, sobre o uso e o significado do termo, três campos convergiram ao longo dos séculos para o reconhecimento da função social do autor, no que diz respeito a publicização de ideias e vozes: (1) aquele que permite a continuação, o aumento e a função de porta-voz pela autoria; (2) aquele que cria, inventa e promove ideias; e (3) aquele que possui autoridade, conjuga soberania e poder com sua autoria.

No caso das resenhas situadas na área de linguística "a riqueza da obra está interligada à autoridade do autor. Então, não é a obra que torna importante o autor, mas o autor que torna a obra importante" 5 (p. 103). Os autores citados no trecho anterior - situados na área acadêmica e na vertente linguística - ao destacarem a função do autor como superior a obra, olham para o texto a partir do lugar da análise de discurso. A referência ao autor muitas vezes comparece como uma deferência, um reconhecimento, prevalecendo o elogio e a exaltação. Afinal, quando lemos um livro e nos propomos ao exercício de, além de leitores, nos tornarmos autores de um diálogo com a obra, é porque algo nela nos toca, mobiliza, e nos faz escritores.

Já nas resenhas críticas, os autores devem se posicionar, iluminando e analisando criticamente a obra. Com relação ao livro resenhado - cuja autoria pode estar colocada como obra única, ou organizada, em múltiplas vozes - vale lembrar de Foucault 6 ao destacar quatro aspectos associados à função autor no texto: (1) de propriedade de ideias, e responsabilidade sobre as quais tem que responder academicamente; (2) de teor argumentativo e clareza na exposição de ideias; (3) o estilo; (4) heterogeneidade que pode se expressar na pluralidade da ação de criação.

Um dos indicativos da autoria da resenha vem no reconhecimento de que a mesma tem um título, e segue com referências citadas e utilizadas como suporte para o diálogo analítico. As discussões sobre o gênero resenha, situadas no artigo de Alves Filho \& Alves 5, partem da distinção entre uma resenha acadêmica e uma literária. Tal distinção nos encaminha a assumir, por exemplo, que em CSP são as resenhas acadêmicas que estão no foco de interesse.

Em CSP os manuscritos submetidos para avaliação na seção Resenhas, em geral, podem vir a apresentar dois grandes problemas de partida: (1) com relação ao livro/obra resenhada, a mesma não cumpre critérios acadêmicos; (2) a ausência de um tom autoral comprometido com uma descrição dos capítulos, reproduzindo uma apresentação acrítica do livro.

Frente ao primeiro problema faz-se necessário olhar para uma publicação, e saber reconhecer a diferença entre um livro - com conselho editorial, editora comercial pertencente à Associação Brasileira de Editores Científicos, ligada a uma editora universitária ou reconhecida pelo campo de estudos - e uma obra de referência, que mesmo sem as características anteriores, ainda assim ganha valor de obra. Nesse último caso, uma obra publicada pode operar como documento, que congrega posicionamentos de agências internacionais, intelectuais do campo, ativistas, policymakers. Podemos ter tanto o livro no primeiro formato, como o livro como $e$-book, como livro de referência publicado por uma agência internacional, nacional e organização da sociedade civil.

Com relação ao segundo problema que indica recusa e compromete a publicação, seu contraponto aqui, pedagogicamente esclarecido, deve primar por algumas características: a leitura crítica, a análise precisa e de campo, a capacidade de síntese, acionando autores e localizando conceitos centrais em seus limites e alcances, valorizando interpretação e um diálogo com eixos centrais da obra. Cabe ainda, quando o tema está na interface com o campo das políticas públicas, acionar um certo estado da arte nesse contexto, como suporte 
inicial do texto. Em algumas resenhas, quando é uma obra de único autor e/ou um autor reconhecido no campo, pode valer uma incursão breve sobre seus antecedentes e argumentos. Nisso, pode ser importante retomar uma breve biografia do autor, o que se torna um desafio quando é uma obra organizada e de múltiplas autorias. Outro destaque a ser assinalado, quanto ao ponto dois, e que orienta uma boa resenha, é buscar o que poderiam ser os pontos fracos na obra, e como o autor os enfrentou.

Entendemos que esse caminho precisa, portanto, de uma construção autoral, um argumento, um fio condutor, que opera como antídoto ao tom descritivo, da armadilha de apresentar a obra como uma reprodução fria de seus capítulos, seções. Mesmo que caiba uma breve apresentação, esta deve estar colocada no interior de uma análise, com quantidade de referências adequada. O conteúdo principal da resenha deve ser direcionado para o desenvolvimento da análise crítica da obra.

A resenha crítica não substitui a leitura do livro, mas deve convidar os possíveis interessados a se tornarem leitores, oferecer a mão, envolver, abraçar e convidar para visita à leitura. O autor que se propõe de forma espontânea, ou é convidado por corpo editorial de CSP para elaborar uma resenha crítica de um livro, se torna antes de tudo um leitor arguto, que irá estabelecer com a obra resenhada um diálogo crítico. E cabe destacar que a resenha crítica publicada na CSP cumpre a função de estimular a atualização bibliográfica e o amadurecimento do campo da Saúde Pública/Saúde Coletiva.

E aqui, cabe valorizar a presença de Clarice Lispector ${ }^{1}$ em nossa epígrafe. Como um abraço, como uma água que envolve, a autora nos inspira a recordar, trazer ao coração a necessidade de fazer arte, sejam pinturas ou escrituras, conquistando prazer e companhia. Nesses duros tempos de pandemia, ler e escrever, assim como revisitar os livros pode representar a resistência necessária a seguir, e fazer convites a novos/outros leitores e autores. 


\section{Informação adicional}

ORCID: Martha Cristina Nunes Moreira (00000002-7199-3797).
1. Lispector C. Água viva. Rio de Janeiro: Francisco Alves; 1993.

2. Mansur V, Guimarães C, Carvalho MS, Lima LD, Coeli CM. Da publicação acadêmica à divulgação científica. Cad Saúde Pública 2021; 37:e00140821.

3. Coeli CM, Carvalho MS, Lima LD. A importância da pergunta de pesquisa na análise de dados epidemiológicos. Cad Saúde Pública 2021; 37:e00091921.

4. Vidal EIO, Fukushima FB. A arte e a ciência de escrever um artigo científico de revisão. Cad Saúde Pública 2021; 37:e0063121.

5. Alves Filho F, Alves LS. Gênero resenha: a construção da figura do autor em textos linguísticos e literários. Entremeios: Revista de Estudos do Discurso 2015; 10:99-107.

6. Foucault M. O que é um autor. Lisboa: Passagens; 1969. 